\title{
Mourning Songs and Human Pasts among the Kotas of South India
}

\section{Citation}

Wolf, Richard. 2000. Mourning songs and human pasts among the Kotas of South India. Asian Music 32(1): 141-183.

\section{Published Version}

doi:10.2307/834333

\section{Permanent link}

http://nrs.harvard.edu/urn-3:HUL.InstRepos:9918824

\section{Terms of Use}

This article was downloaded from Harvard University's DASH repository, and is made available under the terms and conditions applicable to Other Posted Material, as set forth at http:// nrs.harvard.edu/urn-3:HUL.InstRepos:dash.current.terms-of-use\#LAA

\section{Share Your Story}

The Harvard community has made this article openly available.

Please share how this access benefits you. Submit a story.

Accessibility 


\section{Mourning Songs and Human Pasts \\ Among the Kotas of South India \\ Draft for submission to Asian Music (February 16, 2000)}

Note: " = common, non-technical terms used in English, terms I have coined, and other common uses of quotation marks.

" = literal translation of Kota terms

For some fifty years now the Kotas of the Nilgiri hills have been arguing about whether or not they should celebrate the 'dry death' ceremony (varld_v)--a memorial cremation for all men and women who have died during the year. What are the cultural and religious implications of this local argument? I hope to show that changes in rituals such as this may not only lead to changes in cultural philosophy (in this case soteriology) but may in fact be said to constitute those changes. ${ }^{1}$ In this case, by deciding to change their mortuary rituals, Kota have significantly reorganized and reconfigured components of their culture and consciousness which are crucial to the construction of identity. These include Kota perceptions of and relationships to their past(s), interpretations of cultural geography, and distribution of spiritual power to men and women.

${ }^{1}$ This is the second in a series of articles (cf. Wolf 1997a) attempting to illustrate how music and rituals come to actively contribute cultural meaning, either by affecting other cultural domains or by serving as unique exemplars. This article attempts to locate cultural change within the possibilities of a local cultural system. In several forthcoming articles, I will extend and broaden the arguments presented here about music and emotional ambivalence. 
The Kotas number about 1500, speak a distinct and ancient Dravidian language and live in seven villages, scattered widely throughout the Nilgiri hills along the western borders of the southernmost Indian state of Tamilnadu. ${ }^{2}$ Most of the Kota population is now clustered within a short bus ride from Ooty city, one of the most popular tourist sites in India. Although they are classified by the government as a "tribal" people and maintain a staunch sense of cultural independence, the Kotas are also a modernized artisan-peasant community who share aspects of everday culture and religion with nearby Hindus.

Kota indigenous gods are not embodied in permanent, anthropomorphic forms, as are Hindu gods, but rather, inhabit natural forms like fire, stones and trees or tools associated with hunting and metalworking--their premodern occupations. The gods inhabit homes, temples and blacksmith shops in these forms. Kota reflect upon the forms of their gods: to many of them, the association between Kota divinity, traditional, subsistence occupations and what in modern times is described as "nature," reinforces the idea that the Kotas are a "tribal" people--indigenous, ancient, authentic, and rooted to the Nilgiri soil as its most aboriginal inhabitants. This primordialist sentiment is central to and embedded in both the symbols and the actual processes of worship.

Although Kotas do not use coconuts or incense in worshipping their own 'father' (ayn_r) and 'mother' (amn_r) gods, they do adopt this Hindu style of worship when worshipping Hindu deities--some of which they have incorporated into their own

${ }^{2}$ This article is based on my own fieldwork in each of the Kota villages, but particularly in the village of Kolm_l where I lived and worked for two years. I have also benefitted from the opportunity to consult the fieldnotes and publications of the late Dr. David Mandelbaum, who began working with the Kotas sixty years ago and conducted regular field excursions to the Nilgiris throughout his life. 
pantheon. For some gods, like Rangan_tar and M_riyamman, Kotas combine a Kota with a Hindu style form of worship. Although Kota religion is different from Hinduism in many ways, there are also many parallels: both Hindus and Kotas worship with fire, music and dance, and find it important to separate places and times of worship from those of menstruation and death (Fig. 1).

Kota musical life is also compartmentalized: Kotas strictly separate music for worship and god from that associated with death and funerals. However, they also perform a less contextually specific type of dance music both for internal functions and for municipal and other occasions outside the community. Ensembles consist of two shawms, called kol, two cylindrical drums distinguished by pitch, called dobar and kin var, and a frame drum called tabatk (Fig. 2). Musicians blow cascading calls on pairs of simple horns, kob, made of brass, to mark important ritual moments or to egg-on coteries of male dancers (See Fig. 4 in "Three Perspectives" article, this volume). These S- and C-shaped horns are important to the overall aesthetic and context of the musical ensemble, but play no systematic role in the creation of melody or rhythm. Kotas also use a large conical drum to signal moments of ritual and cultural importance, such as the moment of death, but there is no system of rhythm associated with it. Men are the instrumentalists but never sing on ritual occasions. Women sing devotional songs (devr $p_{-} t-$-literally 'god songs') at certain ritual junctures and are the primary singers of mourning songs, called_t! (noun form from a Dravidian root which means to move, shake or dance) (See Fig 3). The Dry Death and Cultural Ambivalence 
On the surface, the Kotas of some villages would appear to have given up their 'dry death' ceremonies for the same reasons that many other Indian communities have changed their customs: to emulate high-caste and Western models. Dry death ceremonies once included significant boisterousness, intoxication, a certain degree of sexual license, and spirited competition in an effort to capture and slaughter buffaloes. One of the reasons Kotas have abandoned the ceremony as a whole is that they have been made to feel ashamed of these practices. There is also, I believe, however, another reason: the special problems of Indian modernity have engendered among the Kotas a sense of cultural ambivalence: how are they to incorporate into their identity as modern Indians their relationship with their ancestors?

This second reason is not entirely disconnected from the first: in both cases Kotas seem to be negotiating relationships with non-Kota Hindus, Hinduism, and Tamil society. They have adopted the idea that, after death, Kota souls merge with the same supreme being as do Hindus'--thus implying that at this ultimate level Kotas are just another kind of Hindu. Others oppose the collapsing of Kota into Hindu identity, believing strongly in a distinctively Kota afterworld and in the necessity of completing all the traditional mortuary rites. For these people, the rituals involved in creating and maintaining relationships to the dead are crucial expressions of Kota identity--a Kota identity in which, in life as in death, the Kotas are unique.

Since the dry death ceremony has been discussed at great length in David Mandelbaum's article, "Form, Variation, and Meaning in a Ceremony," I will not attempt again to explicate all the details of this complex event. Mandelbaum wished to describe the mortuary aspect of Kota 
life and develop a set of methodological tools for examining general questions of form and meaning in ritual. My intention in this article is not to consider social-cultural function of these death rituals per se, but rather their spectrum of significance within the range of ritual symbols in one society. I am interested particularly in that aspect of ritual symbolism which relates to a community's construction and subjective experience of the past.

Funerary rites and texts of mourning songs encode among the Kotas multiple, sometimes conflicting sets of perspectives on their forebears. The "human pasts" of this article are reflections about the dead, and by extension, about Kota history as it was embodied by living individuals. Because of the conflict which is probably inherent in the process of dealing with death, and because of the dynamics of Kota interaction with cultural outsiders, the "human pasts" for the Kotas are mutable, contradictory and problematic.

I gave a special name to the kind of past represented in laments and referenced in funerals, the "human past," in order to distinguish it from what I call a "divine past," the collective memory of the Kota tribe as it is associated with the power of the gods and as it is made explicit in ceremonies for the gods (the most important among which is called devr, literally, 'god'). In contrast with the "human past," which is evoked with uncertainty and contradiction, the "divine past" is the result of a utopian and primordialist self-reflection. The past of funerals and laments is person-centered; that of god ceremonies is community-centered; the human past is history-centered; the divine past is mythologically-centered and timeless. Historical circumstances have led the Kotas to selectively emphasize aspects of these ritual complexes and thus 
selectively emphasize ways of incorporating the past into the present and ethnohistory into identity.

\section{Construction of Individual vs. Community Pasts in Mortuary and Divine Rituals}

The ritual complex associated with death significantly emphasizes the individual: relatives of the deceased enact kinship relations (focused on the deceased) by providing ritual gifts and performing particular duties, officiants burn items associated with the dead person as an individual (or as belonging to a particular group: gender, occupation, ritual status or age), and mourners reminisce about the special qualities of the deceased. Mourning songs ( $t !)$ contain specific references to positive qualities of the dead person and/or retell the story of how the deceased came to his or her demise.

Clearly, by banding together to perform a ritual and by enacting kinship relationships, the ties within a village and between villages are also emphasized and a complex typology of tribal solidarity can also be constructed. I wish here to highlight the attention to the individual, however, because this is one of the simple and central points of contrast between worship and death rituals.

Mourning songs in particular come to preserve the memory of the individual beyond the occasion of a particular funeral. In fact they are from their inception forms of memory: composed after the event of death, they are sung informally, usually by women over sixty, in small gatherings of friends or family. Mourning songs are a means of performing and communicating memory, but they are also a means for evoking that feeling of loss associated with memory of a loved one in a generic sense. Although some of the melodies are unique, some are common to a large number of 
songs and these latter are frequently rendered on musical instruments during funerals and dry death ceremonies--thus reminding mourners of one or more of these song texts and prompting them to remember and reflect upon the deaths of others. This process reinforces an important function of music in a funeral: to enhance and amplify the grief of the community in order that the deceased reach the other world safely.

Although memory of an individual constitutes a relationship to one kind of past, there are other kinds of past referenced in funerary rituals, such as the past of the tribe as a whole. For example, it is customary in the dry death to cremate a home-made plant fiber thread along with bone relics from the funeral. The fiber is a reminder of days past, when Kota made their own clothes, and in a more general sense, were self-sufficient. Many other such artifacts and practices are included Kota funerary practices. These reminders of the past are in one sense important markers that a given practice has the special status of being a 'ritual' ( $c_{-}$trm<Sanskrit__stra); on the other, these are not only reminders, but also preparatory gestures for the journey to the 'mother land,' where, according to some, Kotas live on as ancestors (literally 'ones of that land'_ $\left.n \_t+r\right)$ in an extended state of primeval Kotahood, a utopian state, where all live in perfect social and cultural harmony and according to customary law.

The annual ceremony of worship for Kota traditional deities, called devr (literally god), and other seasonal rituals which are also dedicated to the gods, stress not the individual but the unity of the community--in particular the unity of the village. ${ }^{3}$ One

\footnotetext{
${ }^{3}$ Since all the seven villages celebrate their god ceremonies within the same two month period each year they are unable to attend significant portions of those of one another. Funerals, in contrast, always bring members of different villages together.
} 
way this is accomplished is through the communal participation in primordialist activities which are thematically equivalent with small-scale symbols (such as the plant fiber) found during the funeral. A primary act during the god ceremony, for example, is the consumption of one or more special meals composed of food types which the Kotas say were characteristic of their premodern diet: millet and beans with salt (no complex spices). The worship of god, or in this case the enacting of the god ceremony (which in the Kota language is translates literally as 'making god,' devr gicd), involve as signficant components acts which acknowledge the fact that Kota gods taught the Kotas how to cultivate and collect food, to hunt, and to forge metal.

Another central type of act involves performative utterances (c.f Austin 1979) before moments of prayer: 'are we all joined?,' 'we're joined.' In fact, the unity described in these statements is a unity among men: one of the distinguishing features of divine and funerary ritual complexes is the formal separation of men from women in the former and their formal and informal integration ${ }^{4}$ in the latter. In god ceremonies, men and women are each led by a ritual leader of the same sex (mundk_n_n and mundk_n_! respectively); these leaders, which we might call "priests" in contradistinction with the other major ritual office, the "diviner" $\left(t_{-} r k_{-} r n\right)$, are married to one another--these are in all cases first marriages and if one dies the other loses office.

Led by the respective priests, virtually all men and all women perform acts together in the same way and more-or-less at the same time. Any difference between individuals of the same gender and general age is strongly downplayed. As one Kota

\footnotetext{
${ }^{4}$ Including the possibility of sexual union: see Mandelbaum (1954).
} 
friend explained to me when I attended my first god ceremony, although there may be vast differences in the wealth and social status of individual Kotas "we all wear white because, before god, we are all equal. ${ }^{5}$ The participation of all village men in the ceremony is ensured by a formal roll-calling each evening. Nights are spent dancing around a fire in gender segregated dances always beginning with those of the men.

\section{Three Tensions Between the Constructions of Divinity and Death}

Although I have outlined the differences in ritual themes above rather simply, complexities have also arisen: for example, if god ceremonies emphasize unity, why are men and women separated and men's unity and activities privileged? And, if both funerary and god ceremonies make use of primeval symbols, why would one argue that the past of the tribe as a whole is celebrated primarily as a form of divine worship? The complexities cannot be neatly resolved. However, we can explore further some of the issues they raise by examining the kinds of relationships Kotas maintain with their ancestors--relationships about which which I have suggested, Kotas seem to be ambivalent.

Following a review of beliefs about the dead and some of the specific rituals that compose funerals, I will explore some of the basic cultural polarities, or tensions, which seem to exist between and among constructions of divinity and the construction of

\footnotetext{
${ }^{5}$ This is, of course, a widespread "communitas" state associated with central, "liminal" components of rituals in many cultures, but it also invites comparison with specific south Indian examples, such as worship at and pilgrimage to the Sabarimalai Aiyappan temple in Kerala (see, e.g., Daniel 1984). This "communitas" is in important ways opposed to the "structure" of worship at Brahminical temples in south India (such as that of Guruvayur, for example), which permits differential access to worship according to caste and community.
} 
death. The first polarity is cosmological: there is uncertainty as to whether the ancestors are in some way connected with the gods, or whether they maintain some sort of separate existence with separate powers. The second polarity is mapped onto landscape: the locus of Kota divinity is within the village, whereas death is associated with capricious powers located outside of the village. The third is psychological and emotional: conflict exists between the needs to break social-cultural bonds with the dead and, at the same time, to maintain memories of the dead and celebrate their lives.

Each of these polarities is illustrated in the texts of mourning songs. In addition, as will become apparent, the textual meaning of mourning songs is referenced in instrumental renderings of what are regarded as the same melodies. This provides the opportunity for exploring the musicological question of how, in the realm of mourning, vocal music, more-or-less diatonic, maps onto instrumental music, which is not.

\section{Death Rituals}

Normally, Kotas die and are cremated in a set of rituals called the 'green death' $\left(p a c d \_v\right)$--that is, the funeral--the ceremonial cremation of the corpse while it is still fresh: the vital fluids still inhabit the body just as a plant severed from its roots is dead and yet still remains green. Freshly cut stalks are frequently tied to the bier, thus emphasizing this greenness; for young children who have died, this theme is further emphasized: biers must be constructed of green wood.

In the traditional view, the soul of a deceased man or woman would linger near the cremation ground until a second set of rituals was performed. By 'traditional view' I mean the belief system Kotas claim once to have been their own, notwithstanding 
certain divergent attitudes today. The requisite second set of rituals, called the 'dry death,' would culminate in the recremation of a few bone fragments left over from the initial cremation; the bones are dry and one of the central symbolic foods prepared and eaten as a snack during the dry funeral is dry-roasted millet--this in contradistinction not to the food of the green funeral so much as to that of the god ceremony, where the central symbolic food is boiled millet.

Following the proper execution of the dry funeral, the soul was believed to reach the 'mother land' (amavn_l) or 'that country' $\left(n \_l\right)$ a place located on the Western border where the Nilgiris meet Kerala state.

Unlike the neighboring Toda tribe, whose land of the dead lies near that of the Kotas, the Kotas are not particularly interested in the afterlife and maintain little in the way of stories concerning it. ${ }^{6}$ The current paucity of traditions concerning the dead may reflect a waning of traditional knowledge. As early as 1937, however, Prof. David Mandelbaum also reported that the Kotas expressed only vague ideas concerning the afterlife. It may be that the lack of interest in eschatology, and the lack of formal means for preserving and reinforcing beliefs about the afterlife, made it possible for Kotas to develop multiple or alternative perspectives on questions of death and the ancestors.

The appropriateness of funerary ritual called into question

${ }^{6}$ For Toda stories on the other world, see, e.g. Emeneau (1984, 318-22), Rivers (1986 [1906], 397-404) 
Eschatology suddenly became an issue after certain problems arose concerning the enactment of funerals. It is believed that after a death occurs the village is infused with its negative influences ( $k$ r--in other contexts, 'bad' or 'evil')--what is conventionally, if oversimplistically translated as "death pollution" in Hindu society. ${ }^{7}$ Before the cycle of festivals connected with the gods can be performed each year, the village must conduct a 'dry death,' or 'dry' funeral, to remove these influences. But the ceremony is not simply concerned with pollution. "Death" as a social-cultural phenomenon is not over until the second set of rituals is completed. Marriages, for example, are still binding: Kota widowers and widows were in former times permitted to remarry only after the dry funeral had been performed for their spouses.

The green and dry funerals are characterized by different themes. While the green funeral emphasizes the pain of initial separation and the loss of the individual--themes outlined above--the dry funeral emphasizes unity of the entire tribe. Members of each village attend and participate in a number of rituals designed to dramatize this unity. For example, in one ritual called the $j_{-} d y k_{-}$('community-cooked grain') unmarried men and women from each village are paired with one another as surrogate husbands-wives. Each pair shares food off a single leaf (a quintessential marriage-ritual act as well as one associated with interpersonal solidarity in a general sense among the Kotas)--thus enacting and thereby cementing affinal relationships among villages--an organic solidarity of the most basic kind. In another ritual, called

\footnotetext{
${ }^{7}$ For a more subtle analysis of the contagious effects of death on a community see for example Mines' discussion of 'incapacity,' which draws upon Marriott's ethnosociology (Mines 1989).
} 
j_dykup_c ('community costume'), one man from each village dresses up in an elaborate dancing gown and dances a ritual dance--thereby constituting a sort of mechanical solidarity of village patriarchs.

Dry funerals emphasize both social reproduction in this world and prosperity in the next. An adult priest stands on one side of a pure stream, feeds water to and blesses young children who had never before attended a dry funeral. At the end of the dry funeral it was once common practice for young people to seek out new mates, and widows and widowers to have sexual intercourse with appropriately selected new partners. ${ }^{8}$ In both green and dry ceremonies, Kotas used to sacrifice buffaloes and cows. These were believed to accompany the dead to the other world.

A problem arose as the Kotas began to rebel against mistreatment by members of the numerically and politically more powerful Badagas of the Nilgiris. Led by the late anthropologist David Mandelbaum's primary informant, K. Sulli, the Kotas began to abandon certain practices that were looked down upon by high-caste Hindus and considered cruel or prurient by the British. The bovine slaughter, sexual license, and associated intoxication involved in this affair came to be regarded, even by Kotas, with disdain and shame. Sulli's attempts at reform were initially received with considerable resistance and hostility and even now he is remembered as a trouble maker--despite

\footnotetext{
${ }^{8}$ The ritualized sexual practices Mandelbaum mentions in his publications are supported in the many field interviews I have consulted in his fieldnotes, and there seem to be no reason to doubt his findings. In modern times there is no such formal practice and it is considered in extremely bad taste to raise the topic of sex for discussion (particularly with those who would have been of age in the 1930s). From conversing with those whom I could discuss sexual topics freely, it appears memory of this and other ritualized sexual activities has been effectively quashed.
} 
the fact that many of what used to be his 'reforms' are now cultural norms.

Sulli used to sing a song against buffalo slaughter which has not been preserved in oral tradition, but it does appear on two early recordings, one by Arnold Bake from the 1920s and one by David Mandelbaum in the 1930s. Sulli cleverly used the style of the mourning song ( $t !)$ genre to mourn not the deceased, but the buffalo slaughtered on behalf of the deceased.

Excerpt from version recorded by Bake: ${ }^{9}$

im_vd co.km_n_co.ymk_leke c_ydik ayo (la la la ...) The misfortune of the female buffalo has reached god's feet rd peto erdo.m aya Oh father! We scoop up

imd mando.re taco.m aya

r_n ayrigo ...

p_pm_ne v_ci aya Oh father! we strike [and kill] the female buffalo's head The male buffalo cries out in pain Oh Father! You received sin!

Since buffalo slaughter and other, suddenly questionable, practices were at the heart of the dry funeral, the dry funeral was abandoned or underwent considerable transformation. Since the dry funeral was one of the two most important and longest lasting annual communal events in a Kota village, and the only one which did not specifically prohibit corporeal indulgence, its abandonment was met with considerable opposition. Those who advocated doing away with the dry funeral had to argue, in effect, that the Kotas of the old days did not really know what they were doing. They had to abandon the idea that the village remained polluted after the first funeral; they

${ }^{9}$ Transcribed and translated by Richard Wolf with the help of R. Kamatn and other Kolm_1 villagers in 1992. The recording, TEFI 49.3, can be found in the Archives and Research Center for Ethnomusicology of the American Institute of Indian Studies, in Gurgaon, outside of Delhi. 
had to abandon the idea that the dead lived on in a special Kota land of the dead, where they herded buffalos, played music, and occasionally intervened on behalf of the living. Instead, they adopted the vaguely advaita-ved_nta idea that the soul merges with god, and incorporated a Hindu ritual into their green funeral which would effect that transformation. This new ritual consists of placing in a stream and setting afloat, bones and a number of other symbolic objects. As in the analogous strain of Hindu culture, the stream is identified with the river Ganges.

\section{Music and sound in the constitution of death rituals}

In order to further understand Kota philosophies surrounding death, it will be useful to detail and interpret the placement of music and sound in the structure of death rituals. Following the moment of death, a man beats a ritual conical drum called the rtabațk. Since this drum is not loud enough to be heard throughout the village, a few men will then blow large brass trumpets. From that moment until the time the bier is set ablaze, musically able Kotas perform funeral tunes almost continuously (Fig. 4). Special tunes accompany the movement of the corpse out of the house, the carrying of the corpse to the funeral ground, the giving of ritual gifts by kin, the removal of jewelry by widows and widowers (as a sign of mourning), the lighting of the funeral pyre, and the departure of the soul from the body. In former times, a set of special tunes accompanied the sacrifice of buffaloes and cows.

During the dry funeral a similar set of tunes help to constitute the ritual structure. The formal beginning of the sometimes eleven day event (it varies) is the pouring of millet in front of the houses of each of the deceased. Kotas equate this millet with the 
deceased and each member of the village must salute it. As the millet is poured, a special tune is performed and immediately the widows and female relatives of the deceased begin to cry. ${ }^{10}$ The ritual and music effect a metaphysical transformation by ushering into the village the souls of the dead, who are still lingering outside the village near the cremation ground, and giving them concrete form in the millet.

For several nights following the millet-pouring, men and women dance in a special dancing area in front of particular houses of the village. Then on the eighth day, bone relics of the deceased are placed on highly decorated biers and are carried along with a number of symbolic objects to be recremated (See Figs. 5 and 6). At a special 'dry' cremation ground, Kotas sing and dance, sacrifice animals, consume special meals, and sleep together outdoors under a canopy (See Fig 7). Women used to become possessed by spirits of the dead during this time and thus provided a means through which the Kotas could communicate directly with their "human past" (men are sometimes possessed by the gods during this ceremony, see Fig. 8). Finally, early in the morning, when Venus is sighted, a special tune is performed to send the souls of the dead off to the land of the dead. This tune belongs to the class known as the $n \_r$ g_c kol ('join with the land [of the dead] tune'). This class of melodies is considered to contain the most emotive and important of those performed at a Kota funeral; the melodies themselves, like others of profound significance in Kota culture, are comparatively lengthy.

${ }^{10}$ This ritual will considered in more detail in a future article which discusses the contribution of music to the emotional contour of Kota ceremonies. 
One may note phenomenologically that in these funerals instrumental music effects the process of moving the deceased out of the village. The process is physical as well as metaphysical, so as the deceased leaves the village, death, writ large, is also made to leave. In Hindu contexts, the removal of death pollution is seen to be a highly dangerous affair; evil spirits of sorts are seen to potentially be able to affect people or the soul of the deceased; in some cases the deceased may not be appeased and may therefore continue to live on as a ghost. There is a certain validity to comparing Kota with Hindu funerals because the structure and ritual symbols that many funerals of India share would seem to be evidence of early diffusion. But as in all situations in which diffusion is evident, we cannot assume that meanings remain in enduring relationships with the practices with which they may be associated.

Crucial points of transition in the funeral are highly ritualized through music and other types of activity and Kotas consider these moments to be somehow significant or important. Rather than viewing their music as a means for warding off demons (a common explanation elsewhere in India), they view it as a means for demonstrating respect for the dead, creating a proper forum for expressing emotions, and otherwise contributing to a proper send-off--sort of a going away party. So the kol player, K. Puccan, told me, for example, that his dying friend Va. Kamatn (d. Feb. 1992), asked that he play sweetly and evocatively for his funeral, literally in a "pleasantly smelling manner." Although musical functions and meanings are multiple, as are aspects of aesthetic response, it appears that social rather than metaphysical functions are primary. The experience of a musical aesthetic and the absorbtion in one's own mournful emotions seem to function hand in hand in a proper funeral. 
But Kota funerals, like Hindu funerals, are also characterized by a concern for the fastidious ritual side of things: the careful handling of items associated with death and special behavior in regard to spaces temporarily and/or permanently associated with death. A young boy or girl leads Kota green and dry funeral rituals because children are seen to be in some ways impervious to the ill effects of death; priests are not, and must remain separate from most of the proceedings. But very small children are also subject to danger. In one village, all adults complete their ritual obligations by bathing and placing behind their ears a special leaf. This is believed protect young children from any evil of death that may remain attached to the bodies of adults.

\section{Three Tensions illustrated through mourning song texts}

The preceding overview of death rituals and beliefs will allow us now to consider the three previously noted tensions or polarities between constructions of divinity and death: uncertainty as to whether the ancestors are in some way connected with the gods, or whether they maintain some sort of separate existence with separate powers; emotional and psychological needs to both sever and maintain ties with the deceased; and the association of the village with divinity and the surrounding areas with capricious powers and death.

Ritual and music support the idea that the gods are both associated with and distinct from the ancestors. The physical phenomenon of the corpse and the noumenon of otherwordly spirits or ancestors must of course be distinguished and it is scarcely surprising, for example, that the metaphysical residue of death is polluting to

the Kotas as well as to their gods. But although rituals concerning 'god' and 'death' are kept apart both spatially and temporally they also share formal characteristics. The 
children who function as priests in funerals, for instance, must conduct themselves in the same manner as priests for the gods--in some ways they are considered even more pure than their adult counterparts.

The role of adult priests in funerals reflects an ambiguity in god/ancestor relationships. Adult priests are involved in the green funeral principally by their almost total exclusion from it. ${ }^{11}$ In the dry funeral they participate more actively, as for example, the first to consume ritual meals, the agents in a ritual designed bless young chilren, and leaders in special dances. But participation is once again complemented by symbolic distancing: these priests remain, throughout the dry funeral celebration, either at home or in a special part of the cremation ground, separated from the rest of the people by a stream.

\footnotetext{
${ }^{11}$ In the past, priests participate more actively in the green funeral. Perhaps as a consequence of the general processes of change I describe in this article, the ritual categories of god and death appear to have become further dichotomized: thus any involvement of a priest in a green funeral is now considered inappropriate for an officiant in god ceremonies.
} 
The adult priests' participation in the dry funeral signals an increased involvement, or at least the possibility of increased involvement, of the divine as the deceased progresses from being a corpse, to a wandering spirit, to a resident of the mother land. That the divine becomes more and more involved in green and then dry funerals as they gradually unfold is suggested by other rituals as well. For example, as mentioned earlier, most celebrations involving Kota gods call for symbolic demonstrations of village unity. Although I would hesitate to make the Durkheimian move of equating society with deity, the Kotas make explicit a correlation between their social solidarity and divine efficacy. ${ }^{12}$ In this respect it is significant that at the dry funeral, unity of the tribe as a whole is dramatized in bold and unambiguous terms. We saw, for example, that symbolic marriages between families of all villages are effected formally in the act of eating a special meal. ${ }^{13}$ The degree of celebration increases throughout the eleven day affair, and it culminates with the singing of 'god songs' (devr $\left.p_{-} t\right)$--an act which is associated with divinity by definition but also by its form: women dance and sing together in a circle, a form that ensures dancers are unified in the sense of being adjacent to other dancers both on the right and on the

${ }^{12} \mathrm{~A}$ number of traditional stories relate how cattle died and villagers were unable to complete important ritual tasks because of village disunity. The performance of unity is a central symbolic act in all rituals relating to the gods, especially in connection with rain. (See Wolf 1997a).

${ }^{13}$ The meal itself would be forbidden in specific rituals for the gods because it contains meat. Kota gods are vegetarian. Once again analogies between divine and funerary rituals are balanced by specific elements which differentiate them. 
left. $^{14}$ This emphasis on community in god song performance contrasts the emphasis on the individual (both the singer and the subject of the singing) in the performance of mourning songs.

As death in the village is being made to end, rebirth is ritually and literally encouraged: the priests bless young children, and young people scout out marriage possibilities or abscond for recondite assignations. In a least one village, Kurg_j, deities are directly involved in the dry funeral; generally, however, divine possession takes place in god ceremonies. It used to be common in both green and dry funerals for women to become possessed by spirits of the dead--a phenomenon which not only affirmed the power of the ancestors but also constituted a distinctly female realm for significant ritual activity. Men are possessed by gods; women are possessed by demons or spirits of the dead.

One may argue that death and the world of the ancestors are somehow gender-loaded on the female side of the equation. After all, the mediums for the ancestors are female, the land of the dead is the 'mother land,' and the last death rituals, the culminating rituals of the dry funeral, stress regeneration. The ambiguity of whether the ancestors are a part of, or dependant upon the gods, or whether they are separate, seems to be in this way a replication of modern ambiguities in the construction of formal relationships between the sexes: what is the appropriate role of

\footnotetext{
${ }^{14}$ The most generic name for this type of dance throughout Tamilnadu, in the Tamil language, is kummi. The dance is generally connected with auspicious occasions, the propitiation of rain, women's life cycle celebrations, entertainment and worship. Dances of this general form are described in the earliest Tamil literature under a variety of names.
} 
women in Kota ritual, vis-à-vis men, and what is the appropriate public behavior for women and between women and men.

As Kotas have gradually become less comfortable with the dry funeral and the idea of a relatively separate and distinct afterlife, it is perhaps significant that women's possession at funerals--if it occurs at all--is presumed to be false, or the work of demons. At one dry funeral I witnessed, a woman from $M \_n \_r$ village became possessed; the men present cast aspersions on her character and otherwise ridiculed her. This must be considered not only a supression of the powers of the dead, but also part of a wider movement in which Kota women are denied public, expressive roles in the Kota community. ${ }^{15}$ This comes at a time when women are participating collectively in woman's organizations, and individually, in urban professions and government or development organizations.

${ }^{15}$ This is a type of process noted among Hindus as early as 1955 by Bernard Cohn. As high caste Hindus increase their status in a transnational system by moving toward a Western life style, lower castes adopt the code of orthodox Hinduism: "Cam_rs are trying to tighten the authority of the father and place restrictions on the wife. While the th_kur wife is coming out of seclusion, the cam_r wife is being put into seclusion" (Cohn 1955, 67). 
Although the kinds of mediums and priests appropriate for funerals and god ceremonies are differentiated according to age and gender, we have seen that the roles themselves are analogous; likewise, although the green funeral stresses the initial process of separation, a separation of the individual from society and the separation of divine from death-infected spaces, the dry funeral stresses regeneration and provides a ritual field for the negotiation of divine and funerary forms of symbolic behavior. Kota songs provide further evidence that the ancestors and the gods are somehow related, though perhaps complementary, higher powers. The following mourning song belongs to what I describe as a "power of the ancestors" type, a subgenre whose text either narrates or refers to stories in which the ancestors have consoled the living or shown themselves to be powerful--i.e. analogous to the gods. The subgenre constructs an ancestral realm, distinct from that of the gods, which is available to Kotas in times of need. ${ }^{16}$

enav_nat_d_j_enko·mgo n_r_g

Cir_r ko bl tin_d pul tid__mo

un_d n_rud_mo
'Fat leg,' [you] who are my mother, Nerag! what to say? ${ }^{17}$

In the river valley of Sirur you grazed on virgingrass ${ }^{18}$

You drank virgin water

${ }^{16}$ This song is ascribed to one Pulovaj, the mother of the man who was treasurer ( $g o \cdot t k r n$ ) of Kolm_l village in 1991. She sang the song at the varld_v of her father, Bortn. I have collected six versions of the song on tape, and heard many other versions, both instrumental and vocal. The following version, sung by Pa. Mathi, 19 Feb. 1992, is textually one of the most rich

17 'Fat leg' is a nickname for the Buffalo. 'My mother' is a term of affection found in most _t!ls--although usually referring to the deceased. $N_{-} r \_g$ is another name for the buffalo.

${ }^{18}$ The classic mourning song style of using negative verbal stems is employed here. Literally, 'not eaten grass' is used to mean very grass which is very fine, or rare. 


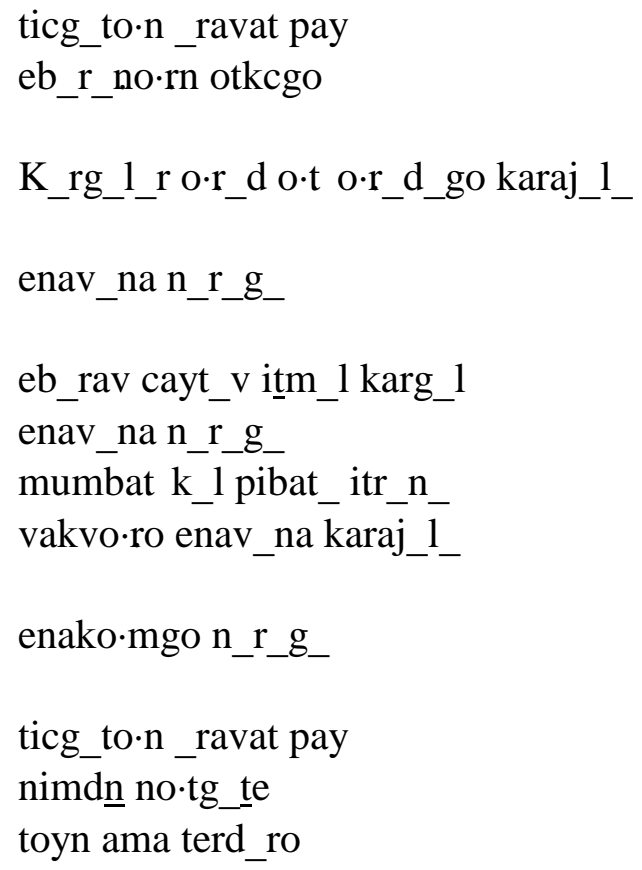

The people of Trichygady, [who have] sixty houses were jealous of our grandfather (See Fig 9)

In Kargal, ${ }^{19}$ don't run as none other has run girl! Karajal! ${ }^{20}$

[You] who are my mother, Nerag

Kargal, if our grandmother is real ${ }^{21}$

Nerag, [you] who are my mother

keeping your front legs in back [i.e. backwards]

you should come, Karajale, my mother

what to say, Nerag?

The people of Trichygady, [who have] sixty houses saying "I will examine yours"

opened the buffalo pen, mother

The text to this song, like many mourning songs, is virtually impossible to understand without knowing the story to which it is attached. In preparation for the dry funeral of a man named Bortn, relatives kept in the cattle pen a large female buffalo which was to be sacrificed the next day. Some men saw the size of the buffalo and became jealous; the night before the buffalo catching ritual was to be conducted, they opened the pen and the buffalo ran away "as no buffalo had run." The next morning the daughter of the deceased spread a cloak down on the ground, sat herself down squarely in front of the pen, and began to weep copiously while singing, "If the

\footnotetext{
${ }^{19} \mathrm{Karg} \_$lis a place near Ticg_r, mentioned, e.g. in Emeneau's Kota Texts (III, 181. n.4) as "a small open place in the forest near the village Ticg_r," and in a number of mourning songs.

${ }^{20}$ Karaj_l is another name for the buffalo. The phrase once again builds upon the negative stem of a verb, to run, reading literally, "running, which is not running, don't run"; the negative stem means in a sense, like no buffalo has ever run before--that is, exceedingly fast.

${ }^{21}$ Karg_l is yet another name for the buffalo. The word for 'real' derives from the Sanskrit satya.
} 
ancestors are effectual, if the land of the dead is genuine, let Karaj_le return to us from the other world, front legs back." As the story goes, the buffalo returned to the pen walking backwards. To my former neighbor in Kolm_l village, Kanymathi (since deceased), this story provided evidence that the world of the ancestors is powerful and that the Kotas of the past could manipulate this power because they lived so righteously. The song provides a living and emotive icon of the event and the story about which listeners may ruminate. 


\section{Separation of Divine and Funerary Spaces}

The separation of temple areas from cremation grounds and the divinely associated part of dry funeral grounds from the ordinary parts are but particular instances of a broader spatial construction of death among the Kotas. ${ }^{22}$ Ritual and music come to associate death with regions outside of, and symbolically in opposition to the village. In particular, death is associated with the forest. The forest as a spatial category is a primary locus for social and spiritual 'otherness' in traditional Kota schemes, a place which holds unpredictable or bizarre forces. This idea is not, of course, one which is confined to Kota philosophy. If the association between the forest and unknown, magical or wild powers is not a universal idea, it is at least a widespread Indian one. We find dark archetypes of the forest throughout the history of Indian literature, where images such as the uncivilized, dark skinned forest dweller, the world renouncer, Siva the aescetic, and demons are rife.

${ }^{22}$ See "Of God and Death" (Wolf 1997b) for an explorations of the slightly more complex phenomenon occuring on village streets $\left(k_{-} r \mathrm{~s}\right)$, where the ritually higher regions are used both for divine and funerary rituals--separated not by space, but by time. 
Kota songs of mourning deploy formulaic devices to mystify the forest and represent it as a place of capricious power, where evil lurks in the form of dangerous or magical animals. Part of the mystification is, I believe, accomplished linguistically: a verb or noun is modified by a word built upon the negative stem of a verb. So instead of singing "you are dead" a mourner will lament, "you sleep not knowing sleep"; a desolate place is cast as "a place where people will not move" or "where crows don't fly"; and the deceased is scolded as the "one who doesn't listen to words"--that is, the one who failed to heed advice against going to the forest or engaging in an activity that is presumed to reponsible for his or her death. ${ }^{23}$

The "Song of Mathi" was recorded by The Madras Government Museum in $1922^{24}$ and is the _t! which remains, both textually and melodically, the most widely known in one variant or another throughout Kota society. It is also an example of a mourning song melody that musicians perform on the kol during a funeral; in each village the story, characters and melodic details differ, thus each villager attending a funeral and hearing the instrumental melody will be prompted to remember the sad story of a death specific to his or her village.

\footnotetext{
${ }^{23}$ Laments in Tamilnadu (opp_ri) generally express a sentiment of loss: those things that can no longer be obtained or accomplished due to the death of the subject tend to be sung in rapid succession, in long lists. This led a Tamil friend of mine, Kabaliswaran, to call the opp_ri a "negative lullaby," because Tamil lullabies tend to provide lists of a reverse nature, lists of what will be given to the baby, lists of what wonderful things the infant can hope to accomplish. The framing of concepts in the negative in Kota mourning songs would seem to fit into this larger scheme.

${ }^{24}$ I thank the Anthropology division of the Madras Government Museum for kindly allowing me to make an audio reproduction of the Song of Mathi.
} 
The musical characteristics of this_t! shed light on the genre as a whole; a comparison of vocal and instrumental versions of this melody also provides insight into how mourning song and instrumental funeral repertoires relate to one another. Although extensive consideration of this piece appears in Wolf (1997b, 360-84), a brief musical excerpt (Ex. 1) from a version sung by V. Mathi (full textual version provided below) and an instrumental version (Ex. 2) performed during a funeral in Kurgo.j village, 1991 serve here to illustrate a few simple points.

In Example 1, each iteration of the melody, here three bars long, begins with an intonation of the initial pitch (the "tonic," although there is no term for this concept in the Kota language) on the syllable "a." The melodic outline established in the first set of phrases (here three, though some versions have four) is normally maintained throughout a piece, although the singer of this example introduces a variation at the end of her performance (not notated).

The melody is rhythmically somewhat flexible and this is typical (here notice some bars are nine beats, others eight); the number of beats in a musical phrase is somewhat conditioned by the density of text in that phrase. Accommodating extra syllables in a single repeated melody is sometimes difficult for singers and many women have complained that the "set-up" (their English usage) is not good for Kota language songs. This lack of good "set-up" is occasioned by the plethora of consonant clusters in the Kota language. The Tamil language, which lacks such clusters, is more suited, in the view of these women, for singing. Comparing the first line as transliterated in the manner one might speak the text (see full text transliteration/ 
translation below) with that in the musical transcription (in Ex. 1) illustrates how vowels are added for musical continuity: e.g. "_tk vo.k_n_" becomes "_tek vo.k_n_".

In the first bar, the symbol "glott." appears over a small rest sign and indicates a typical vocal technique in the _t!l, the use of a glottal stop for melodic articulation. At the end of the third bar appears another technique (indicated by the abbreviation "Br." placed over a small eighth rest and a descending curve): the singer holds the final note, halts abruptly, takes a deep breath, and again intones the initial pitch. This technique too is characteristic of the genre, at least as performed by middle aged-to-elderly women who are considered experts.

Both the glottal stop and the abrupt halting of the final phrase followed by a deep breath may be remnants or stylistic fragments derived from funeral lamenting, although no Kota I spoke ever tried to account for these stylistic features; these features do distinguish the _t! genre from other genres of Kota vocal music (the god song repertoire for instance), however. Furthermore, these techniques can be compared both structurally and descriptively to those of instrumental music. An articulatory stop on the $k o$ ! is impressionistically similar to the vocal glottal stop and is indicated in Ex. 2 by a parenthetical sixteenth rest (first, fourth, and sixth measures, always between repetitions of the "tonic" note).

The intonation of the syllable "a" (preceded by a stop, and a deep breath) in sung_t!ls can be compared with the cadential use of repeated pitches at the bottom end of the instrument's register at the end of each repetition of the melody. I have referred to this type of tone as a "gag" (the "ag" pronounced as "ugh") tone, for Kota musicians 
consistently use the syllable "gag" when they vocalize instrumental melodies (Wolf 1997b). In the middle of a melody, gag tones provide rhythmic punctuation (in contrast, intonation syllables rarely, but occasionally, appear in the middle of a sung melody). Unlike the intonation tone, which may vary, the gag tone is the lowest tone on the instrument's gamut, roughly a major third below the next tone. It stands apart from the other tones of Kota melodies, which are typically conjunct. In this example, the gag tones correspond rhythmically with the two deep pitched strikes of the dobar drum..$^{25}$

In this variant of the story connected with this famous song, a man went to collect bamboo in the forest and met with omens in the form of animals crossing his path: a cat, a dog, a black bird, a frog, and a crow. Upon returning home he discovered his younger sister, dead, lying in the middle of the room. The typical features of this song focus on features of the landscape and the deceptively benign animals the singer encountered in his journey. The implication, here, is that the brother should not have gone away and left his sister alone--presumably to be attacked and killed by a sorcerer.

y_tk vo.k_n_m_yd pitet_rigo. $m \_y d \_$, enangane $m \_y d e$
I'm going to collect bamboo shoots, Mathi Give me some food, little sister Mathi

\footnotetext{
${ }^{25}$ There is some variation in the rhythmic parts, particularly the dobar part, but for the purposes of this notation I have provided a simple, standardized version of the percussion ostinato. It will be noticed that the relationship between melody and percussion ostinato in this example is more straightforward than those of the god tune examples provided in the "Three Perspectives" article (this volume); one reason for this straighforwardness is that this melody is indeed a song. Still, some of the general features I mentioned about Kota instrumental melodies in that article are apparent here. For example the two gag tones occur in places where percussion ostinato and melody line up in a striking way.
} 
$t$ regande $k$ rd re $m$ yde

o.n_n_m_m_yde

p_cadal_yko m_yde

narkav_le kard_re m_yde o.nam_le m_yde

n_y adal_yko $m \_y d e$, enangana $m \_y d e$

k_kayj k_r kard_re m_yde o.nam_le m_yde field' Mathi

kayr viky adalle $m \_y d e$, enangana $m \_y d e$

_k_rv_y kard_re o.nam_I

kepakene adalle $m \_y d e$ enangane $m \_y d e$

k_reg_le kard_na m_yde

$k \_k$ adal_yko $m \_y d e$ enangana $m \_y d e$

penago re kard_re o.n_no.

y_rg_ceke c_d_no.

y_r otire vad_payke vadpene

n_ye narkurlle ork ac_de oyreg_yo

ayo anga $m \_y d e$ enangana $m \_y d e$
Having crossed the threshold, Mathi

Just as I was going, Mathi

a cat crossed my path, Mathi

Just as I was crossing the middle of the yard, Mathi

a dog crossed my path, little sister Mathi

Just as I was crossing the 'lower barley

a black Viky bird crossed, little sister Mathi

Just as I was crossing 'That street mouth'

a frog crossed, little sister Mathi

Just as I crossed the 'Black Place' a crow crossed my path, little sister Mathi

Crossing "Penago $\cdot r$ "

I reached the bamboo area, finished the bamboo collecting, and returned home

You were sleeping, not knowing sleep, in the middle of the room

Oh! My little sister Mathi!

It is quite logical that the regions outside the village would have been associated with fear and death. After all, until relatively recently there were tigers and panthers roaming freely in the Nilgiris; even now, it is dangerous to walk through the fields at night for fear of being impaled on the tusks of a wild boar. Kotas used to believe, and some still do, that death in the form of illness or animal attack was caused by a jungle tribe of (reputed) sorcerers called the Kurumbas.

I believe there is some connection between the idea that the regions outside of 
the village are uncertain and deadly and the ritual necessity of removing death from the village. There is, of course, a rather pragmatic reason for locating the cremation ground outside the village; and perhaps it is merely logical that death itself should be symbolically construed as external to the village. But there is no reason why we must interpret the cultural meanings of the landscape to be one or the other, either instrumental or symbolic; neither are mutually exclusive. Beyond the village boundary is an appropriate place for cremation because death-related activities should not take place near temples and homes, which are in the village; beyond the village boundary is also appropriate for cremation because it is adjacent to the no-man's land of wandering spirits, sorcerers, and because the land of the dead, too, is beyond the village.

If song is one of the forms through which the capricious powers of the forest is encoded, instrumental music is one of the ritual means through which the Kotas transport the dead from the house, through and beyond the village, to the land of the dead: particular instrumental tunes are used each time the bier is moved and when it is finally set on fire. Metaphysically, music substantializes the presence of the deceased in the memorial millet at the beginning of the dry funeral, and later severs the final connection between the living and the dead, sending the deceased's spirit to the land of the dead. Mourning songs operate in an analogous way by constructing death as an extra-village phenomenon--an evil effect of sorcerers and malevolent spirits. The ritual complex associated with death is in this sense centrifugal--it constructs death as a phenomenon of the forest, transports the negative residue death out of the village, ushers the departed spirit out of the village, and provides an anchoring for a rather vague set of Kota beliefs that dead souls live on in another place. 
From the standpoint of cultural geography it is also noteworthy that divinity too is associated with the forest, but in an entirely different way. As suggested in my opening comments on Kota religion, divinity is closely associated with the practice of hunting, with particular trees and stones, and in general with a Romantic view of nature. If the death ritual complex is centrifugal, rituals associated with the gods are centripetal: they provide a cultural filter through which Kotas may guardedly usher into the village the divine aspects of what they perceive as wilderness or nature. The rituals of integration, accomplished at the village level during the god ceremony (unlike the dry funeral, where solidarity is expressed between villages), particularly among men (most of whom, unlike the women, would have been born of the village), and usually in the center of the village, would support this notion of centripetality. The center of the village, either actually or conceptually, is where the gods are and this place is fenced off and for the most part avoided until the god ceremony, at which time it is filled with people and significant activities. ${ }^{26}$ The entire village physically moves toward the divine center and at the same time severs, to the extent possible, relations with matters and people outside the village.

\footnotetext{
${ }^{26}$ The connection between divinely inhabited place and significant activity is an ancient one in India. ksetra a Sanskrit term for sacred ground derives from a verbal root meaning either to dwell or to move--divine space is made through consecration, through physical delineation, through the presence of people and through action. See also Schechner's discussion of Ramlila, in which a space "becomes" what it "represents" (i.e. the subcontinent of India) through the ritual procession/play of the devotees (Schechner 1983, 17).
} 
Mourning songs which highlight the "danger of the forest" stress only one side of the geographic equation--the forest is as much a place of god as it is a place of death and for the spirits of the dead--and the cohabitation, so to speak, between the entities involved allows for a certain degree of ambiguity as to their relationship. ${ }^{27}$

\section{The emotional spectrum}

How humans cope with death has long been a focus of cross-cultural, comparative studies. It is one of the most compelling kinds of cross-cultural subjects because it invites both psycho-biological attempts to understand homo-sapiens as a species and relativist approaches to the cultures of death. Although my training and empirical experiences have biased me towards a cultural relativistic and inductive approach, I am also compelled to consider questions of broader psychological import: whether or not there certain kinds of emotions all human beings feel when confronted with the physical reality of death, whether there is a limited range of typical human behaviors, and whether such emotions and behaviors can be represented in terms of universal human and social needs rather than (or in conjunction with) specific cultural configurations and historical circumstances.

This is not the place to review the substantial literature on the subject, but one might begin such a review with Malinowski's somewhat psychological-universalist approach to the emotions of death, based on "dominant elements": "love of the dead and loathing of the corpse, passionate attachment to the personality still lingering about the body and a shattering

\footnotetext{
${ }^{27}$ See also Feldhaus (1990) for the ambiguous status of the forest/forest dweller and similar issues regarding the cultural construction of village and forest.
} 
fear of the gruesome thing that has been left over. . two elements [which] seem to mingle and play into each other" $(1954,48)$. One may argue that not all cultures regard the corpse with equal abhorrence. Even in India, with some of the most rigidly defined spheres of purity and pollution, I would venture the sweeping generality that vast numbers of individuals from all but the most elite and sheltered communities cope with the physical presence of a human corpse with far great equanimity than would a middle-class white American--if for no other reason because death and life in its complete biological array is palpable and public. This is especially true in Indian villages, but it is also the case in India's cities. But I do believe that members of every culture exhibit some need to distance themselves from the deceased: physical disgust is perhaps one small component of the larger distancing process. The other obvious psychological need for distancing arises from the pain a mourner experiences when reflecting upon the deceased.

In some cultures, mourners apparently avoid the pain of individual memory by avoiding activities, objects, foods and other sorts of things that remind them of the deceased. Beth Conklin, for instance describes how the Wari' of the Brazilian rain forest emphasize "the need to remove reminders in order to help mourners stop dwelling on thoughts of the dead" $(1995,87)$ and provides cross-cultural, psychological evidence that this may be a universal aspect of mourning (Rosenblatt et al. 1976, 67-85). The Kaluli would also seem to provide a parallel example: they place items used by the deceased along with the corpse not to be used in the afterlife (as among the Kotas), but to "preserve the integrity of the dead. . . the more grief-sticken and angry the next of kin. . the more of the dead man's possessions. . " Voluntary taboos are maintained until the responsible witch has died "or at least until the pain of death has receded from memory." (Schieffelin 1976, 159-60). Yet it is difficult to ascertain whether reminders are 
of the deceased are removed in order to remove memories, or in fact to intensify those memories. Schieffelin suggests that voluntary food taboos are "memorial[s] to [one's] relationship with the one who has died." $(1976,160)$.

These scholars and many others illustrate the complexity of emotions connected with death--a complexity caused in part by emotions that do not easily resolve into one another. It is difficult if not impossible to come up with suitable names for these emotions which can be compared cross-culturally, ${ }^{28}$ but it is clear that important poles within death-related emotional spectra have to do with attachment and disjuncture. I would like to briefly discuss how the Kota emotional spectrum is enacted through ritual and song, and how the changing face of this spectrum relates to modernity and the reinterpretation of Kota identity through dry funeral rituals.

Many Kota funerary rituals could be viewed, albeit simplistically, as a series of conjunctive and disjunctive rituals: the sonic and musical marking of each movement of the bier creates a spatial and temporal disjuncture, step-by-step separating the

\footnotetext{
${ }^{28}$ Rosenblatt et al claim only to have arrived at a "crude outline" for understanding the "expression of emotion in bereavement." Their discussion is organized around three headings, crying, anger and aggression, and fear. Missing as a fundamental emotion in their discussion is the saturnalian or celebratory aspect of bereavement, present in so many cultures. Responses which are "inconsistent with anger and aggression"--laughter, sexual arousal, singing, and dancing--are not to these authors, apparently, emotions which arise among people by the phenomenon of death itself, but are promoted or encouraged by ritual specialists. These specialists provide a necessary "societal mechnism of suppression" (Rosenblatt et al 1976, 14-21; $35 ; 32$ ). A more subtle cross-cultural study, based on narratives and cultural analysis, not on statistical sociological data considered outside the context of the research for which it was collected (as in the former study), was conducted by Metcalf and Huntington, who rightly noted that emotions expressed at funeral cannot be assumed to be universals, and more to the point, "nor even that similar reactions correspond to the same underlying sentiments in different cultures" (1991, 44).
} 
community and the village from the event of death, while at the same time drawing attention to that separation. The ambient funeral music, played by the same musicians but unconnected with specific rituals, draws mourners deeper into their grief--making them feel their attachment to the deceased more intensely; of course, not all participants in a funeral maintain strong personal attachments to a particular dead person (some may have even been enemies), but the music serves as an emotional vehicle for these mourners also--creating an atmosphere of grief and attachment of a larger, but temporary, social nature.

Kotas have interpreted the sacrifice of a cow (in former times) and the cutting of a thread binding together the two big toes of the corpse (now) as acts relieving the deceased of their sins--they are acts of disjuncture, and clearly mean more to the participants in the rite than to the deceased (even if the metaphysical explanation is, in proper relativist fashion, accepted). Practices such as discontinuing the performance of funeral music and refraining from corporeal manifestation of grief after the bier has been lit and is burning; smashing a clay pot on the dry funeral cremation site ${ }^{29}$ and hurriedly returning to the village (Mandelbaum 1954, 63); and ritual bathing and meals following the green funeral are all at some level ways of separating the community from the phenomenon of death.

\footnotetext{
${ }^{29}$ Similar rites are included in the funerals of many Indian peoples. Although the Kota ritual involves the spilling of clarified butter in a circumambulation before the pot is broken, among many south Indian Hindus, water is spilled from the pot. Moffatt suggests that one of the meanings of the circumambulation is that "something final is about to happen" $(1968,51)$ and the breaking of the pot "suggests the breaking of the worldly relationship between father and son" $(1968,52)$
} 
It has already been observed that some songs of grief focus on the events leading up to the tragedy of death and the evil of certain people or places; many such songs focus exclusively on the feeling of loss or suffering. These songs do not create a disjuncture between the community and the deceased in the manner of some of the rituals outlined above--almost by definition, mourning songs create a connection between the singer and the deceased. ${ }^{30}$ But they do create an aura around death by associating it with mystery, unpredictability, darkness, anti-social elements (sorcers and demons) and anti-societal places (empty places)--the disjunction is an othering, a creation of a separate death-realm. The creation of a world of the ancestors is also a geographical means for representing the difference between positive divine power and positive powers retained by Kotas who have died physically, but endure spiritually.

Some mourning songs are less disjunctive, focusing less on the event of death than on the memory of life, in all its complexites of hardship, happiness, pleasure and pain. In keeping with the individualist theme in ritual and musical genres associated with death, these subtypes of mourning song localize and individualize their subjects, while at the same time employing formulaic devices which announce, in effect, "this is a mourning song." The following example of such a song, "Puy Avo," provides rich details of the deceased's life. It was composed by Puy's older brother and sung (in this version) by her daughter, Cindamani. The text describes the life history of Puy, the

\footnotetext{
${ }^{30}$ One of the Tamil terms for funeral lament is opp_ri, which derives from a root meaning to agree with or compare. The singer "agrees with" in the sense of commiserating with the mourners and "compares" by drawing out memories of the deceased's life and comparing the deceased with great people and things--see for instance the example cited below in which a woman is compared with Indira Gandhi.
} 
happy and the sad, dwelling poignantly on such images as that of her dancing at a god ceremony, dressed beautifully and wearing a silver coin necklace and gold bangles (See Fig 10). Admiring her beauty, onlookers would ask "whose wife is this"? 
"Puy Av" sung by Cindamani of Kom_I village, 8 August 1992

La la la...

enav_puy avo. enak_na puy avo. My mother ${ }^{31}$ Puy, what to say? kurgo.je ko.k_lele kavd_ne mo.le enav_puy avo. Kavdan's daughter Puy, my

La la la...

mother Puy

kavd_neke mo.le_yre perd_ya enav_puy avo. You were born as Kavdan's daughter La la la...

kavd_neke mo.le_yre perdite tav_yr moge_niya Having been born as Kavdan's daughter you became an orphan ${ }^{32}$

enav_p_ckaynavo. enek_na p_ck_navo. My mother 'cat eyes, ${ }^{, 33}$ what to say? La la la...

kavd_neke mo.le _yte perdite

tav_yre mo.le_yp_re

vavrne mo.le_ype idte arkle pat_yo

enavo. puy avo. la la la...

kab_layneke In vartte

_r_lme tav_yr_yp_m idte_lo.cane gicite

enava puy avo. la la la...

arlke payye k_n_yp_me idre arkle patțe

enav_enek_na p_ckayn avo.
Thinking "I was born as Kavdan's daugher

and I became an orphan,"

"I am the daughter of a sonless man" you felt distressed

having married Kab_I father

You reflected sadly "both of us, husband and wife, have become orphans"

You experience difficulty without a separate house for cooking ${ }^{34}$

my mother, what to say?

${ }^{31} \mathrm{My}$ mother is a formulaic term of endearment in these songs, it does not necessarily reflect the kinship relationship of the composer or singer.

32،"Orphan" is a term often used in songs, both of mourning and of worship, to refer to a lonely person in need-either of familial affection or god's blessings. See also Maschio (1994, 205-6) on mourning songs in which "death makes orphans of those who are left behind to grieve."

${ }^{33}$ Nickname for Puy, who had bright green eyes.

${ }^{34}$ Kota joint families or close friends often choose to sleep together in one house or room, but individual husband-wife pairs frequently prepare meals separately in their own houses. 
'cat-eyes mother'

nantn k_ryke o.kv_r_ke

pulvay odo uko.me v_d te

en_ne kab_layne pacire o.n_ya

enava p_ckaynave la la la...

p_r_de p_re pat_ma avo. enava puy avo.

p_r_de p_re patt_ne

em_mne pay_ne p_ptme p_ypaye _yțe odo

idte _lo.cane gicte

enava puy avo. la la la...

mal_rk_ne kab_laynke erkay_yr_ne

gande _yre mal_re kav_yke kabme ercite

pulne andre vad_me p_r_ne patite

mal_t_re tuykire vad_ya enava puy avo. la la . .

tuykire vadite pulvaye _tete

p_r_de p_re pat_ya enava puy avo.

p_r_de p_re patite
"I'll go to my relative's street" you said

"There's a thatched house there, let's go"

You grabbed my father and went ${ }^{35}$

You experienced difficulties such had not been experienced, you denied yourself luxuries ${ }^{36}$

You experienced difficulties such had not been experienced

"Our uncle's house foundation is empty"

You began to ponder

The mountain was like a left-hand to my father Kab_I

Like a boy he chopped down a post from the other side of the mountain, and with great effort, plucked thatch-grass and came

From the mountainous region he hauled it back, my mother Puy ...

Hauling it back he erected a thatched house

You experienced difficulties such had not been experienced, my mother Puy

Experiencing difficulties such had not been experienced,

${ }^{35}$ Knowing the singer, Cindamani, this passage is not merely descriptive, but it also illustrates the independent and bold character of Puy, whom Cindamani takes after.

${ }^{36}$ The term pat_m refers specifically to the dietary restrictions one must undergo when one is pregnant, but more generally to self control and virtue (<Sanskrit pathya, through Tamil, pattiyam). 
kurgo.je ko.k lele medpaye puy avo.

idire p_r_ne v_c_ya puy avo.

_Inum pedume p_r_de p_re patite

enava la la la

medpaye kalne ortite "dress" koytite

kalne pay_ne medpaye eyt_ya enave puyavo. enava puy ava eneko.ma puy avo.

mal_re ko.k_lile panme p_lme g_c_ko id_me ode pemogme o.g_t_m enava la la...

ko.ytg_l_me mal_tk pacroyțe

enava enko.ma puy avo.
In Kurgoj village "Two story house Puy" was the name you earned, Puy mother

Husband and wife experienced hardship such had not been experienced

Breaking the stones for the two story house, dressing them [i.e. making them fit, chipping them to size]

You erected a two story house What to say, Puy mother?

If not even one woman will go to the mountain settlement and brings loads of 'fruit and milk' (i.e. food supplies)

The Kota women will all grab [my mother] and go

my mother, what to say, my mother?

pane $\mathrm{p} \_l e$ andre enava kunmo.tke kun_ce _yte plucking 'fruit and milk' having become dod_cke dod_c_niya a small girl

eneko.ma puy avo.

pan_ne palne andre_rd_I_re

nk_rm_yre vad_ya

enava puy avo. la la la...

kurgo.je ko.k_leke ed_re pede id_ me

kab_I $n$ pede id me enave

taniy_yr_ne madip_ne tad ${ }_{\text {r }}$

_t _ce kav_leke d_re gic_me

enava $p_{-}$ck_n avo. you became an important woman

what to say, Puy mother?

'Goat's route'

Picking 'fruit and milk' on the

You returned proudly

In Kurgoj village when one asks "whose wife is that?"

They say "that's Kab_I father's

wife!," my mother

They gave a separate respect [to you]

In the dancing ground when we

'make god' [celebrate the god ceremony]

My mother, 'cat-eyes mother' 
tirime $^{37} \mathrm{~d}$ _kl valarykite mundlle mind_ya en ava puy avo. la la la ...

_t _ce kav_lle k_c m_le kacite

_tne_c_me ed_re id $m e$

kab_I_ne pede "Indira Gandhi" r_yn_ idr

el_me no.c_ra puy avo. la la la ...

_y ko.k_leke_l_d_ne

et gand_ne_rt_ne enava

Indira Gandhi mo.ynde r_yne

bad_y g_y_de

et_ne m_ne_dve idte

medpaye tve idte

bad_ye k_t_de

kurumb_ne k_t_de

enava puy avo. la la la...

ayrgire cuyrgire it_ya puy avo.

medpay_ne v_t_idte enava puy avo.

nim_mnede pay_ne kav_le arv_lele

ko.y_yre kor_g_te ol_ya puy avo. la la la ...

arv_le kukarce idte
You go in front, like a wild buffalo

In the dancing ground, wearing a coin necklace

when you are dancing, when one asks, "who is that?"

"It's Kab_l's wife, queen Indira Gandhi" they say, and everyone looks, Puy mother

Seven Kota villages are without
[you]
You gave birth to eight sons
Queen with Indira Gandhi's face
Without putting on airs
Having borne eight sons
having erected a two story house
Without showing haughtiness
Without showing naughtiness
my mother, Puy ...
you were patient and self-sacrificing for
your family
you said "I don't need a two-story
house," my mother, Puy
in the small front doorway of your
uncle's house
you were stooped like a chicken
sitting in the small doorway, thinking

[you]

You gave birth to eight sons

Without putting on airs

Having borne eight sons

having erected a two story house

Without showing haughtiness

Without showing naughtiness

your family

you said "I don't need a two-story in the small front doorway of your souse

sitting in the small doorway, thinking

${ }^{37}$ The word appears to have originally meant the Toda buffalo of the sacred t dairy (cf. DBIA 211), which would have been semi-wild and dangerous, but also prominent and revered. 
emo.le cind_m_yne $k \_n a n e ~ i \underline{d t e}$ arkle patete

kolm_l ko.k_lile_ko.ve vad_ri

ko.yte vak_idr idte

emo.Ine v_idre paryd_ya

enav_puy avo. la la la...

enave _lve vit_dte enek_no e_g_bo idte

enede kactume it_me iko.tk idte

enavn no.tlke vad_na puy avo.

uk_rke vadte enavne no.tko.me idre "my daughter Cintamani ${ }^{38}$ is gone!" and feeling sorry

when any Kolm_I village man would come

or any Kota woman from Kolm_I would come

you said to them "tell my daughter to come!"39

When bidding farewell you would say "what shall I say? what to do?"

"Even if I have difficulties, let them be"

I came to see my mother, Puy mother having come inside, I thought l'd see my mother. . .

${ }^{38}$ The same Cintamani who sang this version of the song.

${ }^{39}$ Since Cintamani married a man living in Kolm_1, her mother, who lived in Kurgo $\cdot j$ village, felt lonely for her. 
Celebrating the life of the deceased is not an activity confined to mourning songs, it can be observed in the funeral ritual as well in practices such as dancing--not just at the dry funeral, after the death is formally established as being "over," but even at the green funeral, where the pain of loss is still acute. Custom calls for men to dance at least three times around the bier of a man or woman who has lived a long life (celebration would never accompany the funeral of a person who had died prematurely or tragically). Such celebration, though in different forms, is called among non-Brahmin Tamils a kaly_nacc_vu, a funeral celebrated as a wedding. One of the main conscious reasons for celebrating the funeral in these societies is that the deceased has lived a long, complete life and died at the proper time, within what may be perceived as a "normal" life cycle, and in a proper place--in the village. ${ }^{40}$ But in the codes of caste and (Westernized) modernity in India, celebrating a funeral marks a community as low--there is no way around this--and it is therefore unsurprising that some Kotas are now hesitant to dance at funerals. They have learned high-caste Hindus and Westerners that funerals are supposed to be serious and formal affairs.

${ }^{40}$ Many societies share aspects of this explanation. See, for example, the "good" death among the Mani of southern peninsular Greece (Seremetakis 1991, 76-81). 
Although the modalities of emotion during Kota funerals cannot perhaps be expressed in simple verbal categories, either in English or in Kota, there are further musical systems of classification which may provide insight into how these modalities are articulated. Just as the macro-classification of tunes into 'god tunes' (devr ko!) and 'death tunes' $\left(t_{-} v\right.$ ko!) corresponds with the primary categories of ritual in Kota society, divinity and death, so does the subdivision of death tunes correspond with the basic categories of emotion expressed at a funeral. In former times, Kotas performed a special subgenre of funeral tune, called $k \_r k o l$, to accompany the central event I described earlier, in which men would compete to catch sacrificial buffaloes. These tunes were considered to be different from the strictly mournful tunes, or dukt kols [<Sanskrit duhkha, pain, sorrow], associated with other parts of the funeral. The genre refers to k_r or what might be called "evil of death"--the same word Kotas use for what in other contexts might be translated as death pollution. ${ }^{41}$ My close friend and field assistant explained the difference between $k$ _ $r$ kols and dukt kols in terms of the two prevailing sets of emotions and kinds of activities involved in a funeral--and I think this is key. ${ }^{42}$ The former are associated with a spirit of action, getting the rituals done,

\footnotetext{
${ }^{41}$ I myself am unsure of whether the $k \_r k o l s$ have always constituted a separate genre within the Kota repertory, or whether the genre name actually derived from music Kotas used to play at Toda funerals. Toda second funeral ceremonies are called $k \_r$ [DEDR 1942: $k \ddot{o} \cdot d$ ] in the Toda language--and Kota music played a central role in Toda buffalo catching at these events as well. Now the $k \_r k o l s$ may be played at virtually any time during either the green funeral, or the dry funeral of the Kotas, and no specific practice separates their performance from that of dukt kols.

${ }^{42}$ The implications of these genre distinctions will be further explored in a forthcoming
} 
finding some level of optimism and inspiration within the prevailing conditions. The latter are associated with crying and all the ritual means of expressing separation.

To relate this multiplicity of emotions to my argument concerning ambivalence about the ancestors, I do not claim that the Kotas are in any way confused, simply because the emotional spectrum is complex. Rather I suggest that the festive aspect of memorializing the dead is not valorized among the upper strata of Indian society, nor is the form this festive aspect has historically taken among the Kotas. Thus in confrontation with a national, staunchly Hindu culture the Kotas have had cause for self-reflection. In the process of this self reflection they have begun to downplay the festive aspects of funerals. In green funerals, dancing is found less frequently than it used to be and buffaloes are never sacrificed. If dry funerals are at all practiced they include no contest for catching the buffaloes; although sexual encounters most certainly occur, they seem to be subtle and more hidden than they seem to have been fifty years ago.

A final comment on the dynamics of musical change is in order here. It is perhaps significant that both the $k \_r k o l s$ and this celebratory type of lament continue to be performed, even though other practices have been discontinued. One might say that the stigma of ill-regarded practices does not adhere to the music to which it is related.

\section{Conclusions}

The ambivalence Kotas implicitly express about their relationships to the article on music and the emotional contour of Kota ceremonies. 
ancestors stems from possibilities that already existed within the structure of rituals, musical repertories, and themes from song texts; it is not some kind of mechanical response to Hindu or Western culture. These possibilities, I suggested, were contained in three kinds of polarity or tension. The first concerned the relative independance of the gods and ancestors. I suggested that the gods and ancestors are treated in some similar ways--both can possess humans, both require that their associated ritualists maintain rigorous standards of purity. But although the forms of treatment are parallel to one another, their human agents are set in opposition to one another. Priests for the gods are adult males, while those for the dead are boys or girls. Spirit mediums for the gods are male and those for the ancestors are female. There is also a processual aspect to the involvement of god-related rituals in funerals--as the rituals are conducted from the moment of death until the last moments of the dry funeral, the role of the divine increases. Thus it is perhaps wrong to pose as either/or the question of whether, at the end of the dry funeral, the ancestors go off to the Kota land of the dead to live out their spirit lives, or whether they merge with god. The link between the gods and the dead or the separate powers of the dead can be selectively drawn upon as occasion calls for it. I suggested that certain laments, such as the one about the escape of the buffalo, affirm the supernatural efficacy of the ancestors as a collectivity. Complementing these, there are other songs and stories which, in other contexts, affirm the power of the gods.

The second is the village/forest polarity and the cultural and religious values associated with these landscapes. Certain laments reinforce and codify the notion that the forest is conceptually opposed to the village in the same way that death is opposed 
to divinity. Connected with the idea that death originates and is caused by something outside the village is the idea that the dead eventually should go outside the village to a number of special places. There are three major aspects to this transition. First of all, the lingering effects of death, including defilement but also such social things as bonds of marriage, must be made to leave the village. Secondly, the physical corpse and later the bone relics must be brought to their special places and burned. And finally, the spirit of the deceased must be made to merge with the land of the dead, or with god, depending on how the individual Kota interprets the process. Each of these three kinds of processes is not only accompanied by, but in part effected by particular instrumental pieces.

The third tension concerned the emotions at both kinds of funerals. Just as the role of divinity increases as the processes of green and dry funerals unfold, so do the number of rituals which somehow involve festive emotions. The ambivalence Kotas now express concerning how they are to regard their ancestors is probably most explicity played out in these emotional terms: if the ancestors do continue to live on in another virtually parallel world, it is necessary to provide a proper sendoff so that they can reach that world and live there happily. This necessitates not only the assiduous practice of specific rituals but also a sort of effervescent elaboration on these practices--a bit of panache, a real party. The party closes the circle, brings death back to life. Only after the dry death was celebrated could the god ceremony (an event of joy, though a more solemn joy) be celebrated; in some villages, such as Kurgo.j, where the dry death is celebrated very seldomly but the ideology of its importance is 
maintained, the villagers and their gods are left in a state of perpetual animation for year on end until the dry funeral is enacted.

To put the Kota funerals and soteriological ambivalence in a slightly broader context, one may note that various strains of Christianity have had global impact on the ways cultures view, and therefore ritualize, death. Even in 1939, when Godfrey Wilson asked why "Nyakyusa burials are jolly affairs in comparison to English funerals [and] why the emotional tenor differs from one culture to another" (cf. Metcalf and Huntington $1991,53)$, he was already studying a culture many of whose members had begun to convert to Christianity. New "reassuring" ideas about death (heaven, for instance) removed the fear that was seen as central in motivating some of the distinctive, celebratory aspects of funerary ceremonies. Here, new ideas led to change in ritual practice (or at least to a disinterest in maintaining them assiduously).

A similar process occurred in America between 1830 and 1920, according to James Farrell. In keeping with social and religious currents of the period--especially those stressing a "living beneficent God"--Americans, like the Nyakyusa, became decreasingly fearful of death. In the absence of such fear, Americans were probably less closed to the idea of innovations in funerary practices, such as embalming.

they were consciously impressed by a concurrence of events--and increased concern for appearances in a consumer culture, a strong and widely publicized sanitary movement, surgical pretensions in an age of respected medicine, a privatization of the home, etc.--which disposed them to accept embalming. The decision for embalming was less a conscious choice than an elaborated tendency (Farrell 1980, 7).

The Kota situation, I argue, is slightly different: embarassment of publicly enacting the funerary practices themselves led some of them, I believe, to construct 
new rationalizations about death--ones which obviated the dry funeral practices and the cow- and buffalo-killing during the green funeral. The ideas themselves (the soul merging with some generalized godhead, brahman) were not newly introduced to the Nilgiris in the 20th century, advaita ved_nta ideas had been circulating throughout the subcontinent for a millenium. One might also blame an old scapegoat, the British, noting that their reign hardened the categories of caste and reinforced top-down views of intercommunity hierarchies--thus leading those lowest in the now-more-rigid hierarchy to challenge their position in it. The catalyst for more general societal change may also have been missionary activity (not by any means limited to the British) and the ever-contagious Victorian morality. Though missionaries had virtually no success among the Kotas, the Kotas identified to some extent with individual British people; Kota hunters, especially, bonded with their colonial shikari brethren. Living on the Nilgiri plateau and frequently coming into contact with English people, the Kotas bore witness to the modern, Western elite society that was growing around them in the late 19th and especially the first four decades of the 20th century. Meanwhile, they were being denied admittance to tea stalls in town, and their children denied admission to school. Cultural changes in the direction of High-caste Hinduism and not Christianity would allow the Kotas to maintain basic cultural patterns--albeit with some reinterpretations--and yet earn some respect from the surrounding communities. Kota reforms apparently worked.

Controversies continue over the celebration of the dry funeral. In the mid 1990s the Kotas of Kolm_I village celebrated the dry funeral again--after a gap of nearly 
half-a-century. As a compromise, the opposing factions in the village agreed upon a vegetarian ceremony in which no buffalo was sacrificed and no meat eaten in public. The younger generation, who never suffered from the prejudices that plagued their fathers and grandfathers, are trying to forge a new modern identity that proudly embraces the practices of the past. These new reformers, if we can call them that, look to the dry funeral as one of those special Kota events that ought to be preserved. My impression is that they view the dry funeral as something of a cultural performance rather than an explicit soteriological statement. But as I suggested, the form and content of funerals themselves constitute a theory of what happens to the dead. As such they seem always to be open to variation and strategic reinterpretation.

\section{References Cited}

Austin, J. L. 1979. Performative utterances. In Philosophical papers, 233-52. $3^{\text {rd }}$ ed. Ed. by J. O. Urmson and G. J. warnock. Oxford: Oxford Univ. Press.

Burrow, T. and M. B. Emeneau. 1984. A dravidian etymological dictionary [DEDR]. 2nd ed. Oxford: Clarendon Press.

Cohn, Bernard. 1955. The changing status of a depressed caste. In Village India: Studies of the little community, ed. McKim Marriott, 53-77. Chicago: Univ. of Chicago Press.

Conklin, Beth A. 1995. "Thus our bodies, thus was our custom": Mortuary cannabalism in an Amazonian society. American Ethnologist 22(1): 75-101.

Daniel, Valentine. 1984. Fluid signs: Being a person the Tamil way. Berkeley: Univ. of California Press.

Emeneau, Murray B. 1984. Toda grammar and texts. Philadelphia: American Philosophical Society.

----. 1936-38. Field notes on Kota vocabulary, unpublished

----. 1944-46. Kota texts. 4 vols. Berkeley: Univ. of California Press.á 
---- and T. Burrow. 1962. Dravidian borrowings from Indo-Aryan [DBIA]. Berkeley: Univ. of California Press.

Farrell, James J. 1980. Inventing the American way of death, 1830-1920. Philadelphia: Temple Uiniv. Press.

Feldhaus, Anne. 1990. The image of the forest in the $M \_h$ tmyas of the rivers of the Deccan. In The history of sacred places in India as reflected in traditional literature. Papers on pilgrimage in south Asia, ed. Hans Bakker. Vol. III, Panels of the VIIth World Sanskrit Conference. Leiden: E. J. Brill.

Madras Government Museum. 1927. Gramophone records of the languages and dialects of the Madras Presidency: Texts of passages. Madras: Government Press.

----. 1927. K_ta language 78 record: The song of Mathi. Serial no. 11, plate no. 124. Madras: Government Museum. Calcutta: Gramaphone Co., Ltd.

Malinowski, Bronislaw. 1954. Magic, science and religion. In Magic, science and religion, and other essays, 17-92. Paperback edition. Garden City, NY: Doubleday (Anchor Books).

Mandelbaum, David G. 1954. Form, variation, and meaning of a ceremony. In Method and perspective in anthropology: Papers in honor of Wilson D. Wallis, ed. Robert F. Spencer, 60-102. Minneapolis: The University of Minnesota Press.

----. 1960. A Reformer of his People. In In the Company of Men. ed. Joseph Casagrande. New York: Harper.

----. nd. (Field notes). Bancroft Library collection no. 89/129cz. University of California, Berkeley.

Maschio, Thomas. 1994. To remember the faces of the dead: The plenitude of memory in southwestern New Britain. Madison: The University of Wisconsin Press.

Metcalf, Peter and Richard Huntington. 1991. Celebrations of death: The anthropology of mortuary ritual. 2nd ed., revised with new intro. Cambridge: Cambrideg Univ. Press.

Mines, Diane. 1989. Hindu periods of death 'impurity.' Contributions to Indian Sociology. 23(1): 103-31.

Moffatt, Michael. 1968. The funeral ritual in south India. B.L. thesis, Univ. of Oxford. 
Monier-Williams, Monier. 1990 [1899]. A Sanskrit -English dictionary. Reprint. Delhi: Motilal Banarsidass Publishers Pvt. Ltd. [Originally published by Oxford University Press].

Rivers, William Halsey Rivers. 1986 [1906]. The Todas. Reprint. Jaipur: Rawat Publications.

Rosenblatt, Paul C., R. Patricia Walsh, and Douglas A. Jackson. 196. Grief and mourning in cross-cultural perspective. New haven, CT: HRAF Press. (look this up. p.67-68, getting rid of reminders of deceased).

Schechner, Richard. 1983. Performative circumstance from the avant garde to Ramlila. Calcutta: Seagull Books.

Schieffelin, Edward L. 1976. The sorrow of the lonely and the burning of the dancers. New York: St. Martin's Press.

Seremetakis, C. Nadia. 1991. The last word: Women, death, and divination in inner Mani. Chicago: University of Chicago Press.

Wolf, Richard. 1997a. Rain, god, and unity among the Kotas. In Blue Mountains Revisited: Cultural studies of the Nilgiris, ed. Paul Hockings. Delhi: Oxford Univ. Press.

----. 1997b. Of God and Death: Music in ritual and everyday life. A musical ethnography of the Kotas, south India. Ph.D. dissertation, School of Music, Univ. of Illinois at Urbana-Champaign. 